\title{
Wiasność w ujęciu socjologicznym: zarys problemu
}

PRZEGLĄD KRYTYCZNY

2021 / 3(2): 7-34

ISSN: 2657-8964

DOI: $10.14746 /$ pk.2021.3.2.1

\begin{abstract}
Mariusz Baranowski ${ }^{1}$
${ }^{1}$ Uniwersytet im. Adama Mickiewicza w Poznaniu, Wydział Socjologii, Szamarzewskiego 89C, 60-568 Poznań, Poland. ORCID: 0000-0001-6755-9368, Email: mariusz.baranowski@amu.edu.pl
\end{abstract}

STRESZCZENIE: Celem artykułu jest charakterystyka własności z perspektywy socjologicznej, czy dokładniej - socjoekonomicznej. Chodzi w nim o wyeksponowanie różnicy w podejściu do problematyki własności ze strony prawa oraz socjologii, szczególnie w kontekście badania współczesnych przedsiębiorstw. Przegląd wybranych ujęć własności ma służyć wyartykułowaniu skomplikowanej natury corporate governance, której pełniejsze zrozumienie umożliwia prześledzenia prawnych oraz socjologiczno-ekonomicznych losów tego specyficznego stosunku społecznego.

SŁOWA KLUCZOWE: własność, posiadanie, corporate governance, analiza socjoekonomiczna, socjologia ekonomiczna

\section{WPROWADZENIE}

$\mathrm{T}$ rudno wyobrazić sobie refleksję socjologiczną bez uwzględnienia pewnych jej, zdawałoby się charakterystycznych czy wręcz definicyjnych, zagadnień dotyczących in abstracto lub in concreto określonych obszarów szeroko rozumianego życia społecznego. W naukach społecznych w ogóle, a w socjologii w szczególności, nie sposób abstrahować od problematyki związanej po pierwsze - z władzą, a po drugie - z własnością. Ten drugi element stanowi sedno zainteresowania tego artykułu, w którym dokonam przeglądu stanowisk dotyczących zagadnienia własności (praw własności) ${ }^{1}$. Tego ro-

\footnotetext{
${ }^{1}$ Warto mieć na uwadze, iż „obiektem własności są w rzeczywistości - według przedstawicieli szkoły praw własności - prawa użytkowania zasobów” (Tittenbrun 1995: 10). Zaś sami prawnicy tak oto określają pojęcie prawa własności: „Prawo własności nie jest stosunkiem prawnym (jak utrzymują niektórzy autorzy) lecz prawem, z mocy którego właściciel ma władztwo nad rzeczą. Termin »władztwo« wypełnia w zasadzie całą treść prawa własności, rozumianą w jak najbardziej szerokim ujęciu. Z teoretycznego punktu widzenia własność jest prawem nieograniczonym, jakkolwiek w praktyce może podlegać rozmaitym restrykcjom, zwłaszcza w odniesieniu do nieruchomości. Liczba ograniczeń rośnie w miarę
} 
dzaju zabieg jest niezbędny, aby zrozumieć skomplikowane podłoże merytoryczne the property rights theory, czyli ważnej koncepcji teoretycznej umożliwiającej zrozumienie zawiłości współczesnego corporate governance. Niemniej jednak już na wstępie warto zaznaczyć, że zagadnienie własności może być także ujęte poprzez pryzmat pojęcia władzy, jak na przykład czyniono w prawie rzymskim za cesarza Justyniana, co z kolei spaja owe pojęcia (własności i władzy) w koherentną całość (por. Pels 1998).

Warto mieć na uwadze fakt, iż niektórzy ekonomiści wyróżniają modele teoretyczne systemów gospodarczych na podstawie dwóch kryteriów, z których pierwsze wiąże się z rodzajem własności (chodzi o ogólny podział na własność prywatną lub publiczną), a drugie dotyczy „charakteru procesu decyzyjnego (rynek lub planowanie z systemem nakazów)” (Kozłowski 2004: 10), co jednoznacznie świadczy o istotności pojęcia własności także w ekonomii, o czym chyba nie trzeba szczególnie przekonywać. Również psychologia nie pozostaje bierna wobec tak ważnego zagadnienia, jakim bez wątpienia jest własność (Zaleski 2003), a także wobec problemów bezpośrednio z nią związanych (Tyszka 2004; Zaleśkiewicz 2003). W opracowaniu tym przyjrzymy się wybranym podejściom filozoficznym, a nawet refleksji ludzkiej starszej od antycznej myśli greckiej, by mieć świadomość ogromnego zasięgu i wyjątkowej różnorodności problemu własności. Wszystko to nie zmienia faktu, iż historyczne źródła stosunku własnościowego w wersji precyzyjnie skodyfikowanej wywodzą się z refleksji prawniczej. Dlatego należałoby zacząć od tego wątku, a dokładniej od prawa rzeczowego. Nie sposób w pełni zrozumieć współczesnych przeróżnych interpretacji koncepcji własności bez odwołania się do najwcześniejszych ich wykładni, które - jak okaże się w trakcie tego artykułu - przyczyniły się w znacznym stopniu do:

(a) ukształtowania potocznej wiedzy na temat własności (mocno zakorzenionej w ludzkiej świadomości nawet w dzisiejszych czasach);

(b) powstania nowatorskich podejść, przeczących formalnoprawnej wykładni omawianego pojęcia.

Stąd niniejszy artykuł ma za zadanie wprowadzenie w socjologiczną, a mówiąc dokładniej - ekonomiczno-socjologiczną (Kozyr-Kowalski 2000: 98) problematykę własności, prezentując zarazem stosunek socjologicznie ujętej problematyki struktur własnościowych do tradycji ją poprzedzających (Kodeks Hammurabiego, Biblia, prawo rzymskie, poglądy poszczególnych myślicieli i poszczególnych „szkół” myślenia). Ogniwem stanowiącym płynne przejście do expressis verbis ekonomiczno-socjologicznego ujęcia własności będą w szczególności rozwiązania zaproponowane przez Adama Smitha, Karola Marksa i Maxa Webera, by wspomnieć tych trzech myślicieli, inspirujących po dziś dzień innych badaczy operujących na pograniczu socjologii, ekonomii, prawa i zarządzania. Krok ten jest niezbędny nie tylko ze względu na wymóg eksplikacji problematyki badawczej, ale przede wszystkim jako element łączący współczesne koncepcje struktury własności i nadzoru spółek akcyjnych (w skrócie: corporate gover-

rozwoju stosunków społeczno-gospodarczych. Stąd zakres uprawnień właściciela jest dziś niewątpliwie węższy aniżeli np. w prawie rzymskim” (Rozwadowski 1994: 125).

Charakterystyka własności w jurysprudencji rzymskiej podjęta zostanie jeszcze w tym artykule. 
nance) z tradycją teoretyczną, która przyczyniła się do wypracowania owych narzędzi. Ponadto, rzetelność analizy naukowej wymaga, aby w miarę możliwości wszechstronnie zaprezentować historyczne elementy stosunku własnościowego (zasada korespondencji), które podlegać będą „życzliwej” krytyce ze współczesnych pozycji.

\section{POJĘCIE WŁASNOŚCI}

Etymologicznie rzecz ujmując, słowo „własność (ang. property) pochodzi albo bezpośrednio, albo poprzez francuskie propriété, od łacińskiego proprietas, które oznacza »szczególny rodzaj lub szczególną właściwość rzeczy« i (w postaugustiańskim piśmiennictwie) własność (w angielskim rozumieniu: ownership)" (The New Encyclopædia Britannica 1991: 181). Natomiast sam termin „proprietas wywodzi się z proprius, przymiotnika oznaczającego »szczególny« lub »własny«, w przeciwieństwie do communis, »wspólny«, lub alienus, »obcy, cudzy«” (ibidem).

Niektórzy badacze zwracają uwagę na dominium, które może być równie istotne jak proprietas w analizie etymologicznej pojęcia własności, ponieważ:

Dominium wysuwa na pierwszy plan władzę nad rzeczą i ludźmi jako atrybut własności. Nie pomija jednak majątkowej natury stosunków własnościowych.

Odsyła bowiem do słowa dominus: pan domu, mąż, gospodarz, pan, właściciel.

Dominium oznaczało też w łacinie posiadłość. (Kozyr-Kowalski 2000: 104)2

Chcąc w miarę dokładnie zbadać jurydyczne pojęcie własności, co nastąpi niebawem, w szczególności winno się mieć na uwadze, że „własność nie jest pojęciem wyłącznie prawnym. Stanowi ona także kategorię ekonomiczną" (Ignatowicz 2000: 41) czy dokładniej: ekonomiczno-socjologiczną, jako że trudno rozdzielić te dwa wymiary. Tak w ogóle, to duża część zagadnień o charakterze ogólnospołecznym nie daje się szczegółowo i wyczerpująco „zaszufladkować” tylko do jednego obszaru refleksji naukowej, co nie oznacza, że część naukowców nie próbuje tego czynić.

Bardzo zwięzłą i zarazem bogatą w treść definicję pojęcia własności sformułował Richard Pipes, podkreślając, że:

»Własność« odnosi się do prawa właściciela lub właścicieli, formalnie potwierdzonego przez władze publiczne, zarówno do wyłącznego korzystania z majątku, jak dysponowania nim w drodze sprzedaży lub w jakiś inny sposób [...] W praktyce pojęcie to zakłada istnienie jakiegoś rodzaju władzy publicznej. (Pipes 2000: 15).

Podejście autora książki Własność a wolność wyraźnie akcentuje prawne właściwości omawianego tu pojęcia, co odpowiada treści następnego podrozdziału.

\section{ZAGADNIENIE WŁASNOŚCI W PRAWIE RZYMSKIM}

Nie sposób zrozumieć genezy powstania prawniczego rozumienia pojęcia własności,

\footnotetext{
${ }^{2}$ Richard Pipes utrzymuje, że „najbardziej znana rzymska definicja prawna określała »dominium« jako "prawo do używania i zużycia jakiejś rzeczy w ramach dopuszczalnych przez prawo« (jus utendi et abutendi re sua quatenus iuris ratio patitur)" (Pipes 2000: 30).
} 
które de facto przyczyniło się do stworzenia ekonomiczno-socjologicznego ujęcia tej problematyki, bez nawiązania do prawa rzeczowego, które z „podmiotowego punktu widzenia oznacza uprawnienie człowieka do rzeczy, z przedmiotowego zaś - ten dział prawa, który zajmuje się bezpośrednim stosunkiem człowieka do rzeczy" (Kunderewicz 1995: 100)ํ․ Ponadto, warto mieć na uwadze zakres obowiązywania prawa rzeczowego, gdyż ma ono „charakter uprawnienia nie w stosunku do poszczególnych osób, ale w stosunku do wszystkich, którzy ten stosunek do rzeczy naruszają. Ma więc charakter absolutny. Podobnie ochrona praw rzeczowych ma ten sam absolutny charakter” (Osuchowski 1986: 250). Jest to istotne z punku widzenia także późniejszych ujęć własności, w których na plan pierwszy wysuwa się wspomniany komponent „absolutności”.

Ogólnie rzecz ujmując, „właściwe” początki refleksji na temat własności są ściśle związane z prawem rzymskim ${ }^{4}$, a dokładnie z działem prawa prywatnego (ius privatum), zajmującego się „normami prawnymi dotyczącymi interesów osób prywatnych i chroniącymi te interesy" (Kunderewicz 1995: 4), w odróżnieniu od prawa publicznego (ius publicum), obejmującego ten obszar, który dotyczy „istnienia, organizacji oraz działalności państwa i chroni interesy publiczne” (ibidem).

Chcąc w pełni zrozumieć rzymską wykładnię własności, winniśmy rozpocząć od pojęcia rzeczy (res), przez które rozumieć należy „odgraniczone, dające się opanować i zużytkować twory przyrody, będące przedmiotami uprawnień. Należą tu twory przyrody organiczne i nieorganiczne, obdarzone życiem i martwe, także zwierzęta, a nawet ludzie znajdujący się w stanie niewoli, których prawo rzymskie zalicza do przedmiotów prawa, czyli do rzeczy" (Osuchowski 1986: 244). Wspomniane wyżej określenie „właściwe” można na tym poziomie analizy odnieść do wpływu, jaki wywiera własność w ujęciu prawa rzymskiego na współczesne rozumienie tego terminu. Otóż „formalnoprawne pojmowanie własności”, tj. spadkobierca rzymskiej tradycji, „odznacza się skłonnością do reifikacji, czyli urzeczowienia świata. Redukuje ono do rzeczy ogół obiektów własności” (Kozyr-Kowalski 2000: 110).

Pierwotnym podziałem rzeczy „występującym w ustawie XII tablic ${ }^{5}$, ale znacznie od niej wcześniejszym, jest podział na res mancipi i res nec mancipi, tzn. na rzeczy, władztwo, nad którymi mogło być przenoszone początkowo tylko w drodze czynności prawnej zwanej uchwyceniem ręką (mancipatio), oraz na rzeczy, nad którymi władztwo mogło być przenoszone bez dokonywania tej czynności" (Kunderewicz 1995: 101). Pierwszego rodzaju rzeczy stanowiły „grunty (i służebności gruntowe wiejskie), znaj-

\footnotetext{
${ }^{3}$ Warto pamiętać, że tzw. nowa ekonomia instytucjonalna inaczej niż tradycja rzymskiego prawa rzeczowego ujmuje istotę stosunku własnościowego.

${ }^{4}$ „Właściwe” w znaczeniu siły wywieranej na późniejsze podejścia i naukowe, i zupełnie potoczne. Natomiast jest rzeczą oczywistą, że:

- istniały inne, odmienne podejścia do problemu własności, które zasygnalizowane zostaną w dalszej części;

- przymiotnik „właściwy” nie jest używany w tym przypadku jako pozytywnie wartościujący całą tradycję prawa rzymskiego („właściwy” w tym wypadku to tyle, co istotny z punktu widzenia późniejszych podejść do owej problematyki).

${ }^{5}$ Powstanie ustawy XII tablic szacuje się na około 450 r. p.n.e.
} 
dujące się w rzymskiej własności prywatnej oraz oznaczone wartościowe przedmioty, ważne dla gospodarstwa rzymskiego obywatela - wieśniaka” (Osuchowski 1986: 245). W praktyce chodziło o następujące rzeczy (ibidem):

(1) grunty położone w Italii,

(2) służebności gruntowe wiejskie,

(3) niewolnicy oraz

(4) zwierzęta pociągowe i juczne (woły, konie, osły i muły).

Wymienione wyżej rzeczy miały stanowić „właściwy majątek dawnego Rzymianina” (ibidem), natomiast wszystkie inne przedmioty objęte zostały terminem res nec mancipi.

Inny podział rzeczy wyróżniał res mobiles i res immobiles, tj. rzeczy ruchome, mobilne i nieruchome. Pierwsze były określane jako takie, które „mogą być przenoszone bez zmiany ich istoty” (Kunderewicz 1995: 101), zaś drugie to po prostu „grunty i wszystko to, co zostało z nimi trwale związane” (ibidem). Często ten drugi rodzaj rzeczy określa się jako nieruchomości, gdyż chodzi o „części powierzchni ziemskiej stanowiące odrębny przedmiot własności (grunty), jak i budynki lub budowle (albo ich części, jeśli stanowią odrębną własność) trwale związane z gruntem. W zasadzie wszystko, co znajduje się na gruncie, należy do właściciela gruntu” (Filipowicz 1999: 112) poza szczególnymi wyjątkami, którymi w tym miejscu zajmować się nie będziemy.

Chyba najistotniejszy z punktu widzenia konsekwencji późniejszej analizy socjologiczno-ekonomicznej jest podział rzeczy na res corporales i res incorporales, czyli rozdział na rzeczy materialne i niematerialne, czy jak chcą niektórzy - na rzeczy zmysłowe i niezmysłowe (Osuchowski 1986: 245). Te pierwsze dotyczyły po prostu rzeczy, „»których można dotknąć« (quae tangi possunt), np. grunt, niewolnik, szata, złoto, srebro i wiele innych” (Kolańczyk 2001: 265). Do drugiej kategorii zaliczone zostały „»rzeczy, których nie można dotknąć« (quae tangi non possunt), np. ususfructus użytkowanie, obligatio - zobowiązanie, hereditas - spadek" (ibidem). Jest to niezwykle istotna kategoria, gdyż rzeczy niezmysłowe, będące „tworami abstrakcyjnymi, istniały w oparciu o prawo obowiązujące (quae in iure consistunt). Były to uprawnienia majątkowe, uznawane i chronione, w innych tekstach klasycznych nazywane po prostu iura. Przydatność praktyczna tej nowej kategorii »rzeczy«, powstałej pod wpływem greckim, bywa niekiedy kwestionowana. Przypuszczać jednak można, że pojęcie res incorporales ułatwiało traktowanie praw majątkowych według wzoru rzeczy materialnych, w obrocie prawnym i w procesie. Skoro obligatio była rzeczą, można było wierzytelność z niej wynikającą sprzedać; skoro rzeczą był spadek, można było dochodzić go w całości jednym powództwem” (ibidem). Istnieją kraje, których prawo cywilne traktuje wyłącznie przedmioty materialne jako rzeczy (ibidem: 266 przypis 2.), co może świadczyć o prawdziwej dalekowzroczności prawodawstwa rzymskiego, ale nie oznacza to automatycznie, iż pojęcie rzeczy niezmysłowej nie jest obarczone pewnymi zasadniczymi słabościami.

Szczególnie przydatny z perspektywy teorii praw własności może okazać się po- 
dział rzeczy na res in patrimonio oraz res extra patrimonium, gdyż należy pamiętać, że „W prawie rzymskim nie wszystkie rzeczy mogły być przedmiotem uprawnień osób prywatnych. Niektóre z nich wchodziły w skład majątku poszczególnych jednostek fizycznych. Jak pisze Gajus, były one »w naszym - tj. obywateli rzymskich - majątku« - in nostro patrimonio. Ta kategoria była także określana jako rzeczy będące w obiegu res in commercio. Inne natomiast były wyjęte $\mathrm{z}$ obiegu, znajdowały się poza majątkiem poszczególnych obywateli - extra nostrum patrimonium; nazywano je także rzeczami wyłączonymi z obrotu prawnego - res extra commercium” (Dębiński 2007: 206).

Pojęcie własności już w prawie rzymskim jawiło się jako niezbędny i bardzo istotny element prawa rzeczowego, które wpływało na wiele aspektów ludzkiej aktywności. Nie zawsze precyzyjnie odróżniano samo pojęcie własności od pojęcia posiadania, ale sam fakt braku precyzyjnego wyartykułowania wspomnianej różnicy nie osłabiał istotności podnoszonej problematyki. Nawet w obecnych czasach, kiedy formalnoprawne ujęcie własności nie wystarcza do precyzyjnych badań struktury własnościowej współczesnych podmiotów gospodarczych, gdyż rzeczywistość często wyprzedza wszelkiej maści regulacje prawne, piszący te słowa byłby daleki od poglądu, że prawne pojęcie własności jest w ogóle nieprzydatne w praktyce życia codziennego. Inna kwestia dotyczy istotności wpływu tradycji prawa rzymskiego na współczesne rozumienie tego terminu, stąd rekonstrukcja tego aspektu właśnie w tym miejscu. Otóż:

W prawie klasycznym wykształcono całkowicie prawne pojęcie własności jako stosunku prawnego nadrzędnego nad rzeczami, oznaczając własność także wyrazem proprietas. Juryści klasyczni uważają własność za pełne władztwo prawne osoby nad rzeczą, absolutne pod względem ochrony prawnej. (Osuchowski 1986: 258)

$\mathrm{Na}$ tę definicję oraz bardzo do niej zbliżoną wykładnię z czasów panowania cesarza Justyniana (527-565 n.e.), w której mówi się expressis verbis, że własność to plena in re potestas (zob. Osuchowski 1986: 258; Dębiński 2007: 221), zwrócił uwagę Stanisław Kozyr-Kowalski ${ }^{6}$, podkreślając wpływ pojęcia władzy na zdefiniowanie własności (Kozyr-Kowalski 2004: 101).

Średniowieczną i oświeceniową konsekwencją eksponowania aspektu „pełnego i bezwzględnego władztwa prawnego nad rzeczą” (Dębiński 2007: 221), czyli tradycji prawa rzymskiego, są wyliczenia atrybutów charakteryzujących własność. Mam tu na myśli takie składowe, jak (ibidem: 222):

(a) ius possidendi, tj. prawo do posiadania rzeczy;

(b) ius utendi, tj. prawo do używania rzeczy;

(c) ius abutendi, tj. prawo do zużycia rzeczy;

(d) ius fruendi, tj. prawo do pobierania z rzeczy pożytków;

\footnotetext{
${ }^{6}$ W dwóch wydaniach Socjologii, społeczeństwa obywatelskiego i państwa (2000 i 2004) wdarło się przeinaczenie justyniańskiej formuły, którą przytacza m.in. Wacław Osuchowski. Zamiast terminu potestas jest potetas.
} 
(e) ius disponendi, tj. prawo rozporządzania rzeczą, zbycia rzeczy lub obciążenia poprzez ustanowienie ograniczonego prawa rzeczowego.

Zatem nie bezpośrednio jurysprudencja rzymska, lecz jej wpływ na późniejszą myśl prawną, a w szczególności średniowieczne ius commune (ibidem), przyczyniły się do powstania powyższych atrybutów własności, do których - jak okaże się w następnych fragmentach - nawiązuje się także obecnie.

\section{WŁASNOŚĆ A POSIADANIE}

Na samym początku tego podrozdziału warto podkreślić, iż „pierwotnie nie odróżniano w Rzymie własności od posiadania i nie było ogólnego jej [tj. własności - M.B.] oznaczenia, a wyliczano jedynie poszczególne uprawnienia właściciela” (Osuchowski 1986: 258). Działo się tak prawdopodobnie dlatego, iż pierwotnie Rzymianom „wystarczało [...] ogólne pojęcie władztwa nad rzeczą jako jednego z aspektów władzy ojca rodziny” (Kunderewicz 1995: 104). Zdaje się, że dzisiejsza potoczna praktyka językowa również z dużą dozą swobody traktuje omawiane określenia. Niemniej jednak, w trakcie rozwoju refleksji nad prawem prywatnym znaczenie obu terminów zostało precyzyjnie rozdzielone:

Wielkim osiągnięciem prawoznawców rzymskich było spostrzeżenie, że bezpośredni stosunek człowieka do rzeczy może mieć postać albo faktycznego, albo prawnego władztwa nad rzeczą. (ibidem: 103)

To precyzyjne zdefiniowanie posiadania ${ }^{7}$, rozumianego odtąd jako „faktyczne władztwo osoby nad rzeczą” (Dębiński 2007: 212), mogło być ściśle związane z polityką alokacji państwowej ziemi, na co zwracają uwagę niektórzy znawcy przedmiotu (por. Kunderewicz 1995: 104). Taka argumentacja może tłumaczyć bardzo wyraziste, by nie powiedzieć ostre, stanowisko dotyczące odróżnienia własności od posiadania:

Jurysprudencja rzymska wyraźnie przeciwstawiała pojęcie posiadania (possessio) pojęciu własności (dominium, proprietas), o czym m.in. świadczy wypowiedź Ulpiana: „Własność nie ma nic wspólnego z posiadaniem«-Nihil commune habet proprietas cum possessione (D. 41, 2, 12, 1) $)^{8}$. Jak pisał Paulus: »Posiadanie bowiem jest rzeczą faktu, a nie prawa« - Eam enim rem facti, non iuris esse (D. 41, 2, 1, 3). (Dębiński 2007: 212-213)

Z socjoekonomicznego punktu widzenia, zabieg prawny odróżniający władztwo faktyczne od władztwa prawnego, czyli wyrażonego „przede wszystkim w prawie własności”, i na dodatek wymagający „uznania i ochrony ze strony państwa” (Kolańczyk 2001: 268), daje solidne zabezpieczenie prawne (np. państwu) na wypadek roszczenia

\footnotetext{
${ }^{7}$ „»Posiadanie« odnosi się do fizycznej kontroli majątku, materialnego lub nie, bez formalnego tytułu do tego dobra: jest to posiadanie de facto, a nie de jure. Jest zwyczajowo sankcjonowane wskutek przedłużonego używania lub dziedziczenia po własnych przodkach, co w prawie angielskim nazywa się »nabyciem przez zasiedzenie« (prescription) i jest dochodzone siłą fizyczną oraz milczącym poparciem społecznym" (Pipes 2000: 15).

${ }^{8}$ D. jest skrótem od Digesta Justyniana, a następujące po niej cyfry arabskie precyzują położenie danego cytatu (od księgi do konkretnego paragrafu).
} 
danego podmiotu wobec obiektu posiadania. Naturalnie nie chodzi tylko i wyłącznie o ochronę własności państwowej przed „zawłaszczeniem” przez podmioty prywatne, ponieważ prawny tytuł posiadania (i także własności) może chronić interes jakiegokolwiek indywiduum. Należy pamiętać, że właściciel może być posiadaczem, ale posiadaczem może być także „nie-właściciel”, czy inaczej - właściciel może nie być realnym posiadaczem danego dobra.

Precyzując samo pojęcie posiadania, jurysprudencja rzymska wskazała dwie jego części składowe, tzn. „element fizyczny, określany tradycyjnie jako corpus possessionis lub krótko corpus, oraz element psychiczny, określany jako animus rem sibi habendi, animus possidendi lub krótko jako animus. Elementy te bywają też określane jako zewnętrzna i wewnętrzna strona posiadania” (Ignatowicz 2000: 301).

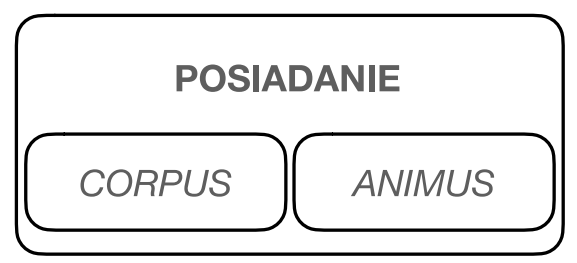

Schemat 1. Części składowe posiadania

Źródło: Opracowanie własne na podstawie: Ignatowicz (2000).

Corpus oznacza dosłownie „fizyczny stosunek osoby do rzeczy - zetknięcie się fizyczne z rzeczą, które daje osobie zainteresowanej możność wyłącznego używania i korzystania z rzeczy” (Osuchowski 1986: 251). Innymi słowy, można określić tę składową posiadania jako zewnętrzną, tzn. materialną stronę possessio, w odróżnieniu od wewnętrznej (w znaczeniu: stanu psychicznego). Animus bowiem to nic innego jak „wola władania rzeczą tak jak właściciel (animus rem sibi habendi), wola zatrzymania rzeczy jako swojej” (ibidem). O posiadaniu mówimy wtedy, gdy występują oba elementy. Gdy brakuje choć jednego, wówczas mamy do czynienia z użytkowaniem, a nie posiadaniem.

\section{UŻYTKOWANIE $\rightarrow$ POSIADANIE $\rightarrow$ WŁASNOŚĆ}

Chcąc sprawę posiadania przedstawić w pełnym świetle, należałoby ją bardziej skomplikować, ponieważ „z punktu widzenia skutków prawnych oraz sposobu nabycia posiadania we współczesnej nauce prawa rzymskiego wyróżnia się następujące rodzaje posiadania: possessio civilis, possessio naturalis (detentio), possessio ad interdicta, possessio iusta i iniusta oraz possessio bonae i malae fidei” (Dębiński 2007: 214). Szczegółowa rekonstrukcja różnic pomiędzy wymienionymi rodzajami posiadania zostanie pominięta, gdyż jest to temat dobrze opracowany w literaturze prawniczej, natomiast rzeczą interesującą może okazać się fakt wywierania określonych skutków prawnych przez samą kategorię posiadania. Chodzi mi przede wszystkim o dwa główne typy po- 
siadania, tzn. o posiadanie interdyktalne i ad usucapionem (zob. Litewski 2003: 213217). Regulacje te dotyczyły tak ważnych kwestii, jak np. nabycie danej rzeczy, które mogło dokonać się na kilka sposobów:

W szczególności posiadacz miał ochronę interdyktalną, mógł zasiedzieć rzecz, nabyć własność przez zawłaszczenie (occupatio) lub przez przekazanie (traditio) res nec mancipi. (ibidem: 213)

Prawo rzymskie było na tyle wszechstronne, że samo posiadanie interdyktalne, zwane przez Rzymian possessio ad interdicta, różnicowano na posiadanie słuszne i niesłuszne. I tak dla przykładu „niesłusznym (wadliwym) nazywano posiadanie nabyte przemocą, potajemnie lub przez precarium od przeciwnika, z którym wówczas przegrano spór interdyktalny" (ibidem: 214).

\section{WŁASNOŚĆ KWIRYTARNA I WŁASNOŚĆ BONITARNA}

Przed kodyfikacją justyniańską, a dokładnie w okresie prawa klasycznego, istniał podział własności na kwirytarną i bonitarną. Ta pierwsza, tj. dominium ex iure Quiritium, „stanowiła najstarszy rodzaj własności uznanej i chronionej według przepisów ius civile. Znana była Ustawie XII tablic; przysługiwała tylko obywatelom rzymskim. Obejmowała res mancipi, nabywane drogą formalnych aktów prawa cywilnego (mancypacji i in iure cessio), oraz res nec mancipi, do nabycia których wystarczała zwykła tradycja. Właścicielom kwirytarnym przysługiwała ochrona według prawa cywilnego, tj. rei vindicatio i actio negatoria" (Dębiński 2007: 222).

Drugi rodzaj własności określany był jako własność bonitarna lub pretorska i miał zastosowanie wtedy, gdy „ktoś miał rzecz in bonis (w majątku), był chroniony pretorską rzeczową actio Publiciana [...] Tzw. własność bonitarna powstawała przede wszystkim na skutek zbycia res mancipi przez traditio. Jeśli zbywca wystąpił potem z rei vindicatio, wówczas nabywcy przysługiwała exceptio rei venditae et traditae (przy kupnie) lub exceptio doli (przy innych tytułach). Ochrona szła więc dalej niż przy zwykłym posiadaniu ad usucapionem" (Litewski 2003: 219). Była to swoista ochrona danej własności, której gwarantem był pretor, a celem wyróżnienia tej formy własności było wyeliminowanie uciążliwego „stosowania przepisów formalistycznego ius civile” (Dębiński 2007: 222), charakterystycznych dla własności kwirytarnej ${ }^{9}$. W tym konkretnym przypadku, rzymska specyfika ujmowania własności jawi się nie tylko jako wyrafinowana refleksja teoretyczna, ale także jako bardzo pragmatyczna postawa, uwzględniająca (i zarazem starająca się zminimalizować) „uciążliwe” konsekwencje procesowe.

\footnotetext{
${ }^{9}$ W sposób zwięzły i klarowny różnicę między własnością kwirytarną oraz bonitarną przedstawił Cezary Kunderewicz (1995: 107-108), który mówił o „chronionej przez prawo cywilne własności kwirytarnej, przysługującej tylko obywatelom rzymskim, oraz własności bonitarnej (pretorskiej), chronionej przez prawo pretorskie. W tym ostatnim wypadku chodziło o ochronę interesów tych osób, które nabyły do swego majątku (bona) res mancipi bez zachowania formalności prawa cywilnego. Pretor przez udzielanie odpowiednich środków ochrony procesowej umożliwiał takim osobom wykonywanie pełnego władztwa nad rzeczą przez okres niezbędny do uzyskania własności kwirytarnej na podstawie posiadania (przez zasiedzenie). Własność cudzoziemców mających ius commercii była chroniona przez pretora za pomocą actiones utiles".
} 


\section{PRZYKŁADY UJMOWANIA WŁASNOŚCI}

Szczególna uwaga, jaką piszący te słowa poświęcił podejściu prawa rzymskiego wobec zagadnienia własności, nie oznacza, że jest to jedyny znany sposób uchwycenia owej problematyki. Nie zostało powiedziane także, iżby Rzymianie byli pierwsi w odkryciu doniosłości praktycznej i teoretycznej pojęcia dominium, choć precyzja i szczegółowość wywodu w tym konkretnym wydaniu jest naprawdę imponująca (również ze względu na kształt współczesnego prawa prywatnego i współczesnej refleksji nad własnością).

Wybrane przykłady praktycznego i/lub konceptualnego sposobu rozpatrywania kwestii własności można rozpocząć od Kodeksu Hammurabiego, który datuje się na XVIII wiek p.n.e. Już w tak odległym świadectwie historycznym, ba, w pierwszych jego paragrafach pojawiają się regulacje dotyczące akadyjskiego makkurûm, bušûm, które tłumaczy się jako majątek, własność (zob. Kodeks Hammurabiego 1996: 81). Nie tylko wolni obywatele, ale również niewolnicy mieli prawo do własności prywatnej (Stępień 1996: 40-41), tworząc ciekawą i postępową strukturę społeczną, jak na ówczesne czasy. Kodeks Hammurabiego w wielu miejscach (paragrafach) regulował praktykę dotyczącą w sposób pośredni lub bezpośredni własności (mienia), czyniąc tym samym stosunki własnościowe ważnym elementem życia społeczno-gospodarczego.

Nie inaczej rzecz się ma z Biblią, która także nie mogła pozostać bierna wobec tak ważnej problematyki, dotyczącej - na różnych poziomach - każdego indywiduum ludzkiego. Pojawiają się pewne problemy interpretacyjne związane ze stylem tej „świętej” księgi, w której znajdujemy przypowieści, alegorie, specyficzną symbolikę, i miedzy innymi dlatego: „Z jednej strony - czytamy, że bogactwo jest skażeniem dla psychiki i przeszkadza człowiekowi w osiągnięciu zbawienia. »Łatwiej wielbłądowi jest przejść przez ucho igielne niż bogatemu wejść do królestwa niebieskiego« (Marek 10; 25). Z drugiej strony otrzymujemy pouczenie, że bogatemu jeszcze Opatrzność przysporzy dóbr: »Kto ma, temu będzie jeszcze więcej dane, a kto nie ma, będzie mu zabrane« (Mateusz 13; 12)” (Zaleski 2003: 20).

Powyższy cytat odnosi się do Nowego Testamentu, lecz podobne zależności mają miejsce w „starej” części Biblii, która doczekała się socjologicznej analizy stosunków własności. Izabela Jaruzelska w taki oto sposób przedstawiła cel swojej pracy Własność w prawie biblijnym: „[...] skoncentrowanie uwagi na samej Biblii w zakresie przejawiającej się w niej własności pojmowanej ekonomiczno-socjologicznie. Ta problematyka stanowi jeden z etapów prowadzących w dalszych badaniach do odtworzenia biblijnego społeczeństwa jako całości, tzn. wydzielenia w nim w sposób bardziej precyzyjny, niż to zostało tutaj uczynione, ekonomicznych oraz pozaekonomicznych struktur, a także wzajemnych zależności między nimi. To zagadnienie integralnie związane jest z wyodrębnieniem klas, warstw (stanów) oraz innych możliwych zbiorowości społecznych" (Jaruzelska 1992: 193).

Wspomniana wyżej autorka, zajmując się zagadnieniem stosunków własności w Starym Testamencie, zauważa, iż nie jest to bynajmniej pierwszy przypadek analizy treści zawartych w Biblii z perspektywy społeczno-historycznej, choć w przytoczonym przez nią przykładzie nie można mówić o refleksji czysto socjologicznej. Ma Izabe- 
la Jaruzelska na myśli Maxa Webera (w szczególności jedną jego pracę, 1994), który „sięga do samego tekstu biblijnego, ponieważ, jak stwierdza w innej swojej pracy na temat gospodarki w społeczeństwach antycznych, Stary Testament stanowi praktycznie jedyne źródło informacji o pewnych etapach dziejów Izraela” (ibidem: 11). Ten argument znacząco wzmacnia ambitny cel analizy własności w przekazie biblijnym, lecz autorka zaznacza, że jej badania są intencjonalnie ograniczone do poziomu socjologicznego, dlatego, by móc abstrahować od wielu opracowań np. archeologicznych i historycznych, które również wypracowały szereg stanowisk i hipotez na temat stosunków społecznych w Izraelu z czasów starotestamentowych.

W celu chociażby skrótowego i powierzchownego zaprezentowania tego, jak aparatura socjologiczna nadaje się do analizy tak odległej rzeczywistości, posłużmy się przykładem własności wspólnej. Otóż zagadnienie własności wspólnej zostało sprowadzone przez Jaruzelską do „udzielenia odpowiedzi na pytanie, czy środki produkcji należące do właścicieli służą jedynie im samym i ich rodzinom, czy również innym osobom" (ibidem: 73). Odpowiedź na tak postawione pytanie jest niejednoznaczna, tzn. zależy od kontekstu, który został dość wszechstronnie określony ${ }^{10}$.

Przejdźmy teraz do odmiennej tradycji intelektualnej również zajmującej stanowisko wobec zagadnienia własności. Platoński model państwa idealnego, w którym występowały trzy klasy, charakteryzował się występowaniem własności prywatnej tylko w klasie rolników, kupców i rzemieślników (zob. Reale 1997: 295), a i w tym przypadku mówiło się o umiarze. Natomiast strażnicy musieli zadowolić się własnością wspólną, ponieważ: „Jeżeli oni posiędą ziemię na własność i domy, i pieniądze, to porobią się z nich gospodarze i rolnicy, zamiast strażników. I staną się panami i wrogami innych obywateli, a nie sprzymierzeńcami. Będą nienawidzili drugich, a drudzy ich i będą nastawali na drugich, a drudzy na nich i te zasadzki wzajemne wypełnią im całe życie. $\mathrm{O}$ wiele więcej i bardziej będą się bali wrogów wewnętrznych niż zewnętrznych, a to już będzie krótka droga do zguby ich własnej i do zguby reszty państwa” (Platon 1994: 162-163).

Forma własności wspólnej strażników została rozciągnięta na wspólnotę kobiet i dzieci, a wszystko razem prowadziło do swoistego platońskiego komunizmu, którego motywacja „jest zdecydowanie spirytualistyczna i niemal ascetyczna” (Reale 1997: 304), a dla innych stanowiła świadectwo społeczeństwa totalitarnego (Popper 1999; 1993a; 1993b).

Arystoteles w sposób polemiczny (by nie powiedzieć krytyczny) ustosunkował się

\footnotetext{
${ }^{10}$ Oto próba socjologicznego ujęcia tejże kwestii: „KE [Kodeks Przymierza wraz z Księgą Wyjścia 20, 22-23, 33 - M.B.] dostarcza przykładów ukazujących, że dobra wytwarzane pracą Izraelitów - prywatnych posiadaczy ziemi, prywatnych posiadaczy lub właścicieli bydła i małej trzody służą także osobom spoza ich rodzin, co by wskazywało na pewne stosunki wspólnej własności. Należy zwrócić uwagę, że własność wspólna, jako element struktury ekonomicznej jakiegoś społeczeństwa, może uzewnętrzniać się w sposób przedmiotowy, tzn. za pośrednictwem pewnych obiektów wspólnie użytkowanych, np. łąk i pastwisk, lub tylko przez pewne stosunki zawiązujące się w używaniu środków produkcji znajdujących się w prywatnym posiadaniu albo własności, a które w pewnych sytuacjach stają się wspólnym dobrem. Dla odróżnienia od pierwszej sytuacji tę drugą postać można określić jako współwłasność prywatnych posiadaczy lub właścicieli” (Jaruzelska 1992: 73).
} 
do poglądów Platona m.in. na temat własności. Twierdził on, iż „do pewnego stopnia [...] powinna własność być wspólna, zasadniczo jednak musi pozostać prywatną" (Arystoteles 1964: 47-48). I choć Stagiryta słynął z formułowania stanowisk pośrednich („Arystotelesowski złoty środek”), to w tym specyficznym przypadku nie ma mowy o niedomówieniach - „lepiej jest, by własność była prywatna, a stawała się wspólną przez użytkowanie” (ibidem: 48), dlatego, że „ci właśnie, którzy mają wspólną posiadłość i wspólnie na niej gospodarują, o wiele więcej popadają w zatargi aniżeli ci, co mają własność prywatną" (ibidem: 49).

Już przy okazji pism Arystotelesa uwidacznia się związek między własnością a efektywnością, czyli ten aspekt porównywania różnych form własności w oparciu o pewne formy praktycznie pojętej efektywności, który stanowi istotny wątek socjoekonomicznych analiz: „Dla Arystotelesa własność była bodźcem sprzyjającym zwiększaniu efektywności ekonomicznej. Dowodził, że jeśli zasoby nie mają właściciela, to nie będą dobrze użytkowane” (Morawski 2001: 229).

Ten rodzaj argumentacji pojawiał się też u innych badaczy i stanowił podstawę racjonalizacji decyzji dotyczących wyboru określonych stosunków własnościowych, które są uznawane za bardziej efektywne ekonomicznie od innych.

Warto dwa słowa powiedzieć na temat stosunku ojców Kościoła do własności, co wiąże się bezpośrednio z poglądami greckich filozofów. Św. Augustyn nawiązywał do myśli Platona i neoplatonizmu, zaś św. Tomasz z Akwinu do Arystotelesa. Zatem stosunek Kościoła do własności prywatnej także ulegał zmianom, aż ostatecznie „nie wymagano od bogatych zrzeczenia się własności; nie pojawiły się też sugestie zmiany systemu społeczno-gospodarczego. Zaakceptowano prywatną własność, charakteryzującą zarówno stosunki niewolnicze, jak i feudalne. Odrzucono jednak rzymską interpretację prawa własności, głoszącą nieograniczone prawo właściciela do dowolnego używania swojej własności. Chrześcijańska myśl oparła się na wykładni judaistycznej, wyraźnie oddzielając prawo do prywatnego posiadania od prawa do społecznego użytkowania” (Zagóra-Jonszta 2007: 42). Bardziej szczegółowe omówienie stosunku ojców Kościoła wobec zagadnienia własności znajduje się w pracy Czesława Strzeszewskiego (2003: 155-208) $)^{11}$.

U Tomasza Hobbesa nie ma mowy o własności czy prawach gwarantujących sprawiedliwość bez umowy społecznej, w wyniku której powstaje państwo (Lewiatan) (Hobbes 1954: 126-127). Dlatego też w „stanie natury nie było własności prywatnej i wszyscy ludzie i pod tym względem byli równi, nie było biednych i bogatych, to przez zawarcie umowy społecznej ludzie zdobywają prawo do własności; prawo pozbawienia obywatela własności ma tylko suweren - dlatego, że sam stoi ponad prawem. Ale z drugiej strony suweren stoi na straży własności prywatnej - gdyby miała ona być zagrożona z jakiejkolwiek strony” (Tomasz Hobbes i Lewiatan 1954: XVI).

W Dwóch traktatach o rządzie Johna Locke'a znajdujemy pokrewne stanowisko wobec poglądów Hobbesa co do istoty umowy społecznej w kontekście problematyki własności (abstrahując od oczywistych różnic w poglądach obu autorów):

\footnotetext{
${ }^{11} \mathrm{Na}$ tę bardzo cenną - z punktu widzenia problematyki własności - pozycję książkową zwróciła moją uwagę Grażyna Musiła.
} 
Tym wielkim i naczelnym celem, dla którego ludzie łączą się we wspólnotach i sami podporządkowują się rządowi, jest zachowanie ich własności. (Locke 1992:

251)

Zwolenników takiego stanowiska jest dużo więcej. Jerzy Szacki mówi, że „ochrona własności jest dla Hume’a' ${ }^{12}$ (podobnie jak przedtem dla Locke’a) zasadniczym warunkiem trwania społeczeństwa, a zamach na nią największym jego zagrożeniem" (Szacki 2004: 107).

Niemniej jednak Locke zwrócił uwagę na bardzo interesujący aspekt własności, a mianowicie na pracę, która okazuje się bardzo istotnym elementem powstania własności prywatnej: „Mimo że ziemia i wszystkie niższe istoty są wspólne wszystkim ludziom, to jednak każdy człowiek dysponuje własnościa swej osoby. Nikt nie ma do niej żadnego uprawnienia poza nim samym. Możemy więc powiedzieć, że praca jego ciała i dzieło jego rąk słusznie należą do niego. Cokolwiek zatem wydobył on ze stanu ustanowionego i pozostawionego przez naturę, złączył ze swą praca i przyłączył do tego, co jest jego własne, uczynił swą własnością” (Locke 1992: 181).

Jean Jacques Rousseau genezę powstania własności widział w świetle nieco odmiennym od swoich poprzedników z Wysp Brytyjskich, albowiem w Rozprawie o pochodzeniu i podstawach nierówności między ludźmi stwierdza:

Ten, kto pierwszy ogrodził kawałek ziemi, powiedział »to moje« i znalazł ludzi dość naiwnych, by mu uwierzyć, był prawdziwym założycielem społeczeństwa. (Rousseau 1956: 186)

Powstanie własności pociąga za sobą konsekwencje negatywne, co paradoksalnie Rousseau zaczerpnął $\mathrm{z}$ „aksjomatu mądrego i wytrawnego Locke'a, nie ma krzywdy tam, gdzie nie ma własności” (ibidem: 195-196) - jak sam bardzo obrazowo i ironicznie zauważył. Są też fragmenty prac francuskiego myśliciela, które są bardzo bliskie poglądom Locke’a, np. jeśli chodzi o związek między pracą a własnością (ibidem: 200), choć jednocześnie pojawienie się własności wypaczyło samą pracę (ibidem: 197), a nawet więcej: „[...] z jednej strony rywalizacja i konkurencja, z drugiej sprzeczność interesów i zawsze to ukryte pragnienie korzyści własnej ze szkodą dla drugich; wszystkie te klęski, to pierwszy skutek własności i nieodstępny ciąg dalszy nierówności w jej pierwszych początkach” (ibidem: 203).

Przykładowe podejścia do problematyki własności można by mnożyć, wspominając poglądy Hugo Grotiusa, Samuela von Pufendorfa (zob. Tuck 2001), Thomasa Morusa (1993) i wielu innych, także socjologów: m.in. Augusta Comte’a, Emila Durkheima, Georga Simmla. Dodatkowo łatwo można dokonać podziału wspomnianych wyżej autorów na zwolenników własności prywatnej i ich przeciwników, co pozwoliłoby przyglądać się historii myśli społecznej poprzez stosunek do określonej formy własności. Prawdopodobnie byłoby to zadanie heurystycznie płodne (pomimo aspektu czysto deskryptywnego), gdyż pozwalałoby wytyczać kierunki rozwoju poszczególnych szkół myślenia, monitorować ich zmiany w określonych odcinkach czasu itp.

Natomiast piszący te słowa zamierza przejść do rozróżnienia socjoekonomicznego

${ }^{12}$ Szerzej na temat stosunku własności u Hume’a - zob. Hume 2005: 389-395. 
i formalnoprawnego ujęcia problematyki własności poprzez przyjrzenie się stanowiskom Adama Smitha, Karola Marksa i Maxa Webera.

\section{PROBLEMATYKA WŁASNOŚCI U ADAMA SMITHA, KAROLA MARKSA I MAXA WEBERA}

Adam Smith w swoim głównym dziele z 1776 roku (2007a; 2007b) zajmował się - mówiąc bardzo ogólnie - wieloaspektowym zagadnieniem bogactwa narodów, a bardziej szczegółowo - powiązaniami „między wolnością gospodarczą i polityczną, między prawami prywatnej własności i sprawiedliwym państwem, a także między indywidualnymi osobami kierującymi się częściowo egoistycznym interesem i częściowo troską o konsekwencje swoich działań dla innych" (Landreth \& Colander 1998: 112). Był zwolennikiem własności prywatnej i wolnego rynku, wypowiadając się negatywnie wobec wszelkich form monopolu („skutki monopolu [...] są zawsze i z natury swej szkodliwe” - Smith 2007b: 236) i regulacji:

Każde zakłócenie naturalnego rozdziału kapitału musi przynosić szkodę temu społeczeństwu, w którym powstaje, albowiem bądź odsuwa kapitał od pewnej gałęzi handlu, do której w innych warunkach by podążył, bądź też przyciąga go do takiej gałęzi, od której by kiedy indziej stronił. (ibidem: 267)

Wynika z powyższego, że najbardziej efektywna alokacja kapitału ma miejsce na wolnym rynku, gdzie sam mechanizm rynkowy weryfikuje poszczególne decyzje inwestycyjne. Natomiast władza państwowa jest potrzebna tam, gdzie istnieją duże różnice własnościowe między obywatelami (ibidem: 365). Adam Smith mówi więcej:

Jeżeli władza państwowa jest ustanowiona dlatego, by zabezpieczała własność, to w rzeczywistości jest ona ustanowiona dla obrony bogatych przed biednymi, to jest tych, którzy posiadają jakąś własność, przed tymi, którzy jej nie posiadają. (ibidem: 370)

Z punktu widzenia socjoekonomicznego podejścia szczególnie istotne jest stanowisko Smitha dotyczące wyższości (czytaj: wyższej efektywności) właścicieli nad dyrektorami zarządzającymi danym przedsiębiorstwem. Pragnę jedynie zainicjować ten wątek, gdyż wyraźnie wykracza on poza zakres tego artykułu (por. Baranowski 2011a). Natomiast warto dodać, że Adam Smith reprezentował inny punkt widzenia niż przedstawiciele ekonomiki praw własności:

Ponieważ jednak dyrektorzy [...] kompanii zawiadują raczej cudzymi pieniędzmi niż własnymi, przeto nie można się spodziewać, aby dbali o te fundusze z taką samą starannością, z jaką troszczą się o własne fundusze wspólnicy w spółce prywatnej [...] Dlatego też sprawy takiej kompanii prowadzi się zawsze bardziej lub mniej niedbale i rozrzutnie. Z tego też względu kompanie akcyjne dla handlu zagranicznego rzadko mogły wytrzymać konkurencję prywatnych kupców. (Smith 2007b: 402-403)

Pogląd Smitha względem „tradycyjnych” właścicieli i dyrektorów najemnych jest dość klarowny, a zainteresowanych jego dokładną charakterystyką oraz krytyką odsy- 
łam do pracy Efektywność corporate governance w Polsce (Baranowski 2011a).

Karol Marks i ogromna spuścizna, jaką po sobie zostawił, koresponduje nie tylko z poglądami Adama Smitha (krytycznie się doń odnosząc w wielu miejscach), ale przede wszystkim z problemem własności, który stanowi jeden z centralnych tematów całej jego twórczości. Stanisław Kozyr-Kowalski zauważa ponadto, że „rozróżnienie między prawnym a ekonomiczno-socjologicznym rozumieniem własności występuje zarówno w licznych pracach Marksa, jak i w Wirtschaft und Gesellschaft Maxa Webera” (Kozyr-Kowalski 1977: 47), co stanowi obiekt zainteresowania tego artykułu. Nie trzeba dodawać, że różnic w podejściach Marksa i Webera jest wiele, czego nie powinna przesłaniać konstatacja dotycząca ekonomiczno-socjologicznego ujęcia własności.

Własność w pracach Marksa występuje najczęściej w kontekście opozycji: właściciele środków produkcji - „nie-właściciele” (nieposiadający) środków produkcji. Jest to bardzo istotna dychotomia, gdyż leży u podstaw marksowskiej koncepcji stratyfikacji społecznej. A warto pamiętać, iż zróżnicowanie klasowe stanowiło swoisty motyw przewodni twórczości autora Das Kapital.

„Dla Marksa - zauważają Malcolm Hamilton i Maria Hirszowicz - klasa jest przede wszystkim wyznacznikiem stosunku do środków produkcji i miejsca zajmowanego przez jednostkę w społecznej organizacji produkcji. W społeczeństwie kapitalistycznym istnieją więc dwie podstawowe klasy: burżuazja i proletariat, definiowane przez stosunek do środków produkcji” (Hamilton; Hirszowicz 1995: 8). Ci pierwsi, to posiadacze (właściciele) środków produkcji, a proletariat charakteryzuje się zależnością od burżuazji, ponieważ nie posiada owych środków. Właściwie nie posiada niczego oprócz własnej siły roboczej, którą musi sprzedawać uprzywilejowanej klasie właścicieli. Kozyr-Kowalski, w swojej subtelnej i wszechstronnej analizie prac Marksa, dostrzega szersze spektrum możliwości interpretowania własności. Stwierdza, iż „[...] fundamentalne pojęcia marksowskiej teorii własności: bezpośredni producent - właściciel środków produkcji, nieproducent - właściciel środków produkcji zakładają nietożsamość, różnicę między stosunkiem do środków produkcji a własnościa środków produkcji” (Kozyr-Kowalski 1977: 91-92). Sprawa dotyczy wszechstronniejszego sposobu analizy powyższych pojęć, dlatego że „osoby będące podmiotami identycznego lub zbliżonego stosunku własności mogą się znajdować w bardzo różnym stosunku do środków produkcji, tzn. pracować bezpośrednio produkcyjnie, wykonywać pracę pośrednio produkcyjną w procesie produkcji lub pracę pośrednio produkcyjną w sferze wymiany dóbr materialnych i pieniędzy, działać w jakiejś instytucji nadbudowy, opartej na pracy nieprodukcyjnej, mogą wreszcie nie wykonywać żadnej pracy o charakterze produkcyjnym lub nieprodukcyjnym i uzyskiwać zasadnicze środki utrzymania dzięki samemu stosunkowi własności” (ibidem). Oznacza to, że za często przytaczaną opozycją: właściciel środków produkcji vs. bezpośredni producent stoi bardzo zróżnicowana i wielowymiarowa rzeczywistość, która wymaga wypracowania dodatkowych narzędzi analizy (takich jak wyraźnie zdefiniowany „stosunek własności” i „stosunek do środków produkcji”).

Rolę własności w koncepcji Marksa można rozpatrywać także z pozycji teorii for- 
macji ekonomicznych społeczeństwa ${ }^{13}$, gdzie wyróżnione zostały następujące systemy (Wesołowski 1979: 336):

(a) wspólnota pierwotna;

(b) niewolnictwo;

(c) feudalizm;

(d) kapitalizm;

(e) socjalizm ${ }^{14}$.

Do powyższych należy dodać komunizm, rozumiany jako najwyższa forma rozwoju procesu historycznego (o ile w socjalizmie istnieć mogą pozostałości poprzedniego, tj. kapitalistycznego systemu, o tyle komunizm jest formą wolną od wszelkich kapitalistycznych determinant).

Elementami różnicującymi poszczególne formacje ekonomiczne są przede wszystkim: system własności i system pracy. Przy czym pamiętać należy, iż system własności wpływa na pracę.

We wspólnocie pierwotnej zarówno własność, jak i praca ujmowane są w kategoriach kolektywnego posiadania. Marks zauważa, że w tej formacji „ziemię traktują ludzie z naiwną bezpośredniością jako własność wspólnoty, wspólnoty produkującej i reprodukującej siebie w żywej pracy. Każda jednostka zachowuje się jak właściciel lub posiadacz jedynie jako członek, jako member tej społeczności” (Marks 1986: 371).

Przy przejściu do niewolnictwa, by posłużyć się określeniem badaczy twórczości Marksa, uwidacznia się istotna zmiana, która wyraźnie odróżnia tę formację od wspólnoty pierwotnej. Jest to także tendencja o szerszym zakresie, gdyż nie tylko niewolnictwo, ale także feudalizm i kapitalizm „są antagonistycznymi, a dwa pozostałe [tj. wspólnota pierwotna i socjalizm - M.B.] nieantagonistycznymi sposobami produkcji” (Wesołowski 1979: 336). Próbując scharakteryzować niewolnictwo, dokonamy tym samym wstępnego opisu pozostałych dwóch antagonistycznych formacji, ponieważ: „Stosunki produkcji właściwe antagonistycznym sposobom produkcji posiadają szczególną cechę: są to stosunki oparte na prywatnej własności środków produkcji. W stosunkach tych utrwala się strzeżona systemem norm i sankcji społecznych określona zasada panowania pewnych grup ludzkich nad środkami produkcji, procesem produk-

\footnotetext{
${ }^{13}$ Zamiast określenia „teoria formacji ekonomicznych społeczeństwa” często w literaturze przedmiotu występują terminy takie, jak: „formacja społeczno-ekonomiczna” lub „społeczno-gospodarcza”.

${ }^{14}$ Sam Marks w Zarysie krytyki ekonomii politycznej (1986: 370-379) przy okazji analizy formacji poprzedzających produkcję kapitalistyczną posługuje się następującymi terminami:

(a) formacja pierwotna (własność pierwotna naturalnych warunków pracy pracujących jednostek);

(b) formacja azjatycka (azjatycka forma własności);

(c) formacja antyczna (antyczna forma własności);

(d) formacja germańska (germańska forma własności).
}

Można przeczytać także o burżuazyjnym społeczeństwie i socjalistycznym (czy na najbardziej zaawansowanym etapie - komunistycznym). 
cji i rezultatem produkcji” (ibidem).

Zatem już w niewolnictwie musiała istnieć własność prywatna (indywidualna), a system pracy w stosunku do pewnych kategorii społecznych wyróżniał się przymusem. Włodzimierz Wesołowski, opisując antagonistyczne klasy społeczne, stwierdził, iż w „społeczeństwie niewolniczym są nimi panowie niewolników i niewolnicy; w społeczeństwie feudalnym - feudałowie i chłopi; w kapitalistycznym zaś - kapitaliści i robotnicy" (ibidem: 337).

Przy okazji feudalizmu i kapitalizmu warto dodać, że oprócz występowania własności indywidualnej, system pracy, choć zasadniczo różnił się od formacji niewolniczej, to wciąż pozostawał pod kontrolą klas uprzywilejowanych (feudałów lub właścicieli środków produkcji).

Socjalizm, jako nieantagonistyczny sposób produkcji, w którym własność prywatna miała tracić na znaczeniu, a stosunki międzyludzkie winny przypominać te ze wspólnoty pierwotnej, miał prowadzić do harmonijnych stosunków społecznych, których ukoronowaniem miał być komunizm.

Z powyższego jasno wynika, że dla autora Kapitału „prywatna własność i rynek deprecjonują i obniżają godność wszystkiego, czego tylko dotkną, wyobcowując w ten sposób jednostki z ich prawdziwej istoty. Tak więc samo istnienie rynków - a zwłaszcza rynków siły roboczej - podważało zdolność ludzi do osiągnięcia prawdziwego szczęścia” (Landreth \& Colander 1998: 268).

Innymi słowy, własność ${ }^{15}$ ujęta jest u Marksa specyficznie ${ }^{16}$, gdyż podporządkowana zróżnicowaniu klasowemu, będącemu jednym z głównych motywów prac tego autora. Nie wchodząc w szczegóły materializmu dialektycznego ani w krytykę Marksa w ogóle, która jest „utrudniona przez to, iż po stuleciu ożywionej działalności interpretatorów nikt już nie wie, co właściwie autor ten twierdził” (Nowak 1991: 48), zajmę się stosunkiem Maxa Webera do problematyki własności.

Otóż Max Weber precyzując podstawowe pojęcia socjologiczne, w taki oto sposób scharakteryzował Eigentum: „Szanse dziedziczenia zawłaszczone przez jednostki lub dziedziczne wspólnoty czy stowarzyszenia nazywamy własnością (jednostek lub odpowiednich wspólnot czy stowarzyszeń), zbywalne - własnością wolną” (Weber 2002: 33).

Pytanie, jakie przychodzi na myśl w tym miejscu, dotyczy roli własności w koncepcji Webera, a także stosunku tego podejścia do ujęcia Marksa, ponieważ - o czym była mowa uprzednio - obydwaj badacze posługują się rozróżnieniem na formalnoprawne i ekonomiczno-socjologiczne ujęcie własności. Już z powyższego fragmentu Wirtschaft und Gesellschaft wynika, iż Weberowskie podejście do kwestii własności jest specyficzne i różne od Marksowskiego. Specyficzne, gdyż definiujące własność, a - jak się okaże za chwilę - również przynależność klasową poprzez określone szanse życiowe

\footnotetext{
${ }^{15}$ Wasilkowski przytaczany przez Tomasza Piwowaruna (1977: 33-34) zauważa, iż „u Marksa terminy własność (Eigentum) i zawłaszczanie (Aneignung) występują niekiedy jako synonimy. Jest jednak oczywiste, że jeden z tych synonimów nie może być uważany za określenie drugiego".

${ }^{16}$ W innej książce Marks zauważa, że „tym, co wyróżnia komunizm, jest nie zniesienie własności w ogóle, lecz zniesienie własności burżuazyjnej” (Marks \& Engels 1979: 53). Chodzi naturalnie o „zniesienie własności prywatnej” (ibidem).
} 
(ibidem: 671). W przypadku różnic wobec podejścia Marksa, sprawa jest nieco bardziej skomplikowana:

Weber zgadza się z Marksem, że pojęcie klasy odnosi się do sytuacji ekonomicznej jednostek, ale na tym zgoda się kończy, gdyż na dalszy plan odsuwa on centralną dla autora Kapitału kwestię własności. Wprowadza wprawdzie pojęcie klas posiadania (Besitzklassen), o których wyodrębnieniu decyduje »naga własność«, ale, po pierwsze, jest to dla niego tylko jedna $\mathrm{z}$ dwóch możliwych ${ }^{17} \mathrm{i}$, po drugie, sądzi, że w nowoczesnym społeczeństwie klasy te tracą swe kluczowe kiedyś znaczenie na rzecz klas zarobkowych (Erwerbsklassen). Inaczej mówiąc, zdaniem Webera o sytuacji klasowej jednostki decyduje teraz nie tyle jej stan posiadania, ile szanse, jakie ma na rynku, sprzedając swe talenty i kwalifikacje. Co może jeszcze ważniejsze, Weber odrzuca Marksowską koncepcję obiektywnego interesu klasowego, wykluczając tym samym hipotezę o przekształcaniu się »klasy w sobie« w »klasę dla siebie«. Według niego nie ma podstaw do traktowania klas społecznych jako rzeczywistych lub potencjalnych podmiotów działania zbiorowego: pojęcie klasy jest narzędziem klasyfikacji, a nie określeniem realnych bytów społecznych, których antagonizm wpływa na dynamikę społeczeństwa. Weber nie sądzi też, aby podział na klasy był podziałem najważniejszym i znajdującym odbicie we wszystkich dziedzinach życia społecznego. (Szacki 2004: 478-479)

Biorąc pod uwagę ostatni fragment dotyczący położenia klasowego $\mathrm{u}$ Webera, to sprawa nie jest aż tak jednoznaczna, jak sugeruje powyższy cytat. Otóż Jerzy Szacki miał na myśli, co potwierdza jego dalszy tok rozumowania, że oprócz klas Weber wyróżnił także stany i partie. Jest to bez wątpienia prawdą, podobnie jak nie podlega dyskusji fakt, iż „położenie klasowe jest wyznaczone przez stosunki apropriacji i własności” (Kozyr-Kowalski 1979: 21). To właśnie teoria apropriacji i własności pomaga zrozumieć „właściwy sens słów Webera, iż »posiadanie« i »brak posiadania« są podstawowymi kategoriami wszelkich położeń klasowych” (ibidem). Na tej podstawie wyróżnione zostały dwie teorie klas: rynkowa i pozarynkowa, a szczegółowa analiza poszczególnych teorii prowadzi do bardzo interesujących konkluzji (zob. ibidem: 2134). Do równie interesujących wniosków prowadzi zestawienie położenia klasowego z położeniem stanowym, które - jak się okazuje - oparte jest na różnych obiektach apropiacji ${ }^{18}$.

${ }^{17}$ Stanisław Kozyr-Kowalski, opisując Weberowskie pojęcie klasy, wyróżnia trzy, a nie dwa, jak chce Jerzy Szacki, typy klas (Kozyr-Kowalski 1979: 30):

(a) klasa posiadania (Besitzklasse);

(b) klasa zarobkowa (Erwerbsklasse);

(c) klasa społeczna (Soziale Klasse).

${ }^{18}$ Analizując położenie klasowe i stanowe, Weber „zakłada, że stosunki apropriacji i posiadania stanowią podstawę nie tylko porządku klasowego, lecz także stanowego. Różnica między klasą a stanem polega zaś na tym, że położenie klasowe jest bezpośrednio wyznaczone przez stosunki własności występujące w sferze struktury gospodarczej społeczeństwa, położenie stanowe natomiast wyznaczają stosunki własności występujące w pozaekonomicznych sferach życia społecznego, zwłaszcza w sferze działań polityczno-administracyjnych. Obiektami apropriacji warunkującej położenie klasowe są 
Podejście Webera do problematyki własności nie jest jednorodne, gdyż zmieniało się wraz z pojawianiem się kolejnych rozpraw, co sugerują badacze (zob. Ford 2010), ale istotniejsza kwestia dotyczy wpływu autora Gospodarki i społeczeństwa na najnowsze koncepcje teoretyczne. Okazuje się bowiem, że duża liczba rozwiązań współczesnych teorii własności, które bezpośrednio „stymulowały” także tytułowe zagadnienia tej pracy, było obecnych już w pismach Webera (Ford 2010). Niemiecki socjolog uważał, podobnie jak Adam Smith, że „każde zawłaszczanie ludzi (niewolnictwo, poddaństwo) lub szans ekonomicznych (monopole odnoszące się do klienteli) oznacza ograniczenie ludzkiego działania zorientowanego na sytuacje rynkowe” (Weber 2002: 82). Nade wszystko był zwolennikiem własności prywatnej, gdyż w „swojej teorii powstania kapitalizmu uznawał przedsiębiorczą organizację własności prywatnej za jeden z głównych czynników racjonalizacji życia społecznego” (Morawski 2001: 232).

Z drugiej strony, Max Weber, łącząc różne podejścia teoretyczne, był jednocześnie świadomy odmienności poszczególnych stanowisk. Dotyczy to także prawniczego i socjologicznego ujęcia problematyki społeczno-gospodarczej. Według Jacka Tittenbruna, rekonstruującego stanowisko niemieckiego myśliciela, „w tym pierwszym [prawniczym ujęciu - M.B.] pyta się: co w idealnym wymiarze obowiązuje jako prawo. A zatem: jakie znaczenie, czyli - jaki normatywny sens powinno się nadawać [...] danemu tworowi językowemu uważanemu za normę prawną. W tym ostatnim [tj. socjologicznym ujęciu - M.B.] natomiast pyta się: co w ramach danej wspólnoty pociąga za sobą faktycznie istnienie szansy, że uczestniczący w działaniu wspólnotowym ludzie, zwłaszcza tacy, których poczynania w rzeczywistości wywierają na nie społecznie istotny wpływ, uznają subiektywnie i traktują w praktyce pewne porządki jako obowiązujące, a więc orientują na nie swe działania” (Tittenbrun 2012).

Przyjrzyjmy się teraz, jak te dwa podejścia (socjologiczno-ekonomiczne i prawne) funkcjonują w kontekście zagadnienia własności.

\section{SOCJOEKONOMICZNE A PRAWNE UJĘCIE WŁASNOŚCI}

Sami prawicy mają świadomość, iż „własność jest wprawdzie kategorią prawa cywilnego, ale jej rola nie ogranicza się do pełnienia funkcji właściwych tylko dla tej dyscypliny. W jakimś sensie jest ona instytucją interdyscyplinarną, instytucją całego systemu prawnego" (Ignatowicz 2000:43). Socjologowie, ekonomiści, specjaliści od zarządzania mogliby rozszerzyć powyższą obserwację, dodając, że własność jest instytucją w szerokim tego słowa znaczeniu, co w tym kontekście oznaczałoby, że wykracza poza wąskie granice formalnoprawnego ujęcia. Powiedzmy więcej - czysto prawnicze rozumienie pojęcia własności (czy praw własności) jest niewystarczające do socjologiczno-ekonomicznej analizy współczesnych form aktywności gospodarczej.

Stanisław Kozyr-Kowalski zauważył w swojej analizie (por. Weber 1985: 57), iż prawne ujęcie własności nie uwzględnia złożonej struktury socjoekonomicznego uję-

przede wszystkim rzeczowe środki produkcji i niezbędna dla ich uruchomienia praca (siła robocza) o charakterze wykonawczym lub kierowniczym. Obiektami apropriacji wyznaczającej położenie stanowe są przede wszystkim rzeczowe środki zarządzania i panowania polityczno-społecznego oraz sama władza zarządzania i panowania” (Kozyr-Kowalski 1979: 139). 
cia tegoż zagadnienia, i stąd: „Formalnoprawne myślenie obejmuje pojęciem własności trzy odrębne jakościowo kategorie stosunków ekonomiczno-społecznych: 1) same stosunki własnościowe; 2) stosunki uwarunkowane własnościowo, czyli nie będące własnością, lecz jej skutkami w gospodarce, systemach władzy, zróżnicowania społecznego, życiu rodzinnym itp.; 3) stosunki doniosłe własnościowo, czyli nie będące własnością, lecz wywierające wpływ na własność pojętą ekonomiczno-socjologicznie” (Kozyr-Kowalski 2000: 104-105).

Do powyższego, prawnego ujęcia własności, można dodać kolejną charakterystykę, zwracającą uwagę na to, że „przedmiotem własności są [...] rzeczy, a podmiotem własności osoby, przy czym nie muszą to być pojedynczy ludzie, chodzi bowiem o tzw. osoby prawne, którymi mogą być np. przedsiębiorstwa, państwa, gminy, miasta, uniwersytety” (Milewski \& Kwiatkowski 2005: 11). Podejście ekonomiczno-socjologiczne - z przeciwnej strony - akcentuje ten aspekt, w którym własność ujmowana jest jako „stosunek między ludźmi, który powstaje w związku z faktycznym i niekoniecznie odzwierciedlonym w przepisach prawa korzystaniem przez ludzi z rezultatów (wyników) działalności gospodarczej oraz dysponowaniem (zarządzaniem itp.) czynnikami produkcji. Przedmiotem własności są tu nie tyle wszelkie rzeczy, ile czynniki produkcji (zasoby naturalne, kapitał, praca ludzka) oraz ostateczne rezultaty działalności gospodarczej (dobra konsumpcyjne), a podmiotem własności są nie tyle osoby prawne, ile raczej konkretni ludzie, tzn. pojedyncze osoby, rodziny, grupy osób, społeczności lokalne, społeczeństwo jako całość” (ibidem).

Z tego, co zostało powiedziane, wynika, iż różnica między prawnym a socjoekonomicznym ujęciem własności dotyczy w istocie definicji podmiotu własności i tym samym samego stosunku własnościowego. Pierwsza propozycja (prawna) skupia się na formalnoprawnej charakterystyce owego podmiotu, zaś ekonomiczno-socjologiczna analiza „schodzi” niżej, starając się zidentyfikować faktycznego (a nie tylko formalnoprawnego) właściciela. W ujęciu prawnym, według Stanisława Kozyra-Kowalskiego, dominuje pytanie o charakterze normatywnym: „Jaki powinien być świat?” ${ }^{\text {. Nato- }}$ miast podejście socjologiczne i ekonomiczne pyta: „Jaki jest rzeczywiście świat?” (Kozyr-Kowalski 2000: 106). I chociaż to drugie stanowisko nie prezentuje się na pierwszy rzut oka wybitnie okazale, to konsekwencje jego zaimplementowania do badania zjawisk gospodarczych są nie do przecenienia, stanowiąc unikatową perspektywę poznawczą (zob. Chmara 1992).

\section{RODZAJE WŁASNOŚCI}

Z socjologicznego i ekonomicznego punktu widzenia najprostszym podziałem własności jest podział na własność prywatną i własność publiczną (państwową) (zob. Shleifer 1998). Naturalnym przedłużeniem tego podziału staje się wyróżnienie przedsiębiorstwa prywatnego oraz przedsiębiorstwa państwowego (zob. Tittenbrun 1996).

\footnotetext{
${ }^{19}$ Prawo, jako doktryna praktyczna, ma „zapewnić działania skuteczne. Dla wielu typów działania skutecznego nie jest niezbędna wszechstronna wiedza naukowa. Można działać skutecznie, opierając się na wiedzy zdroworozsądkowej, jednostronnej i uproszczonej, fikcyjnej i częściowo tylko prawdziwej lub nawet fałszywej" (Kozyr-Kowalski 2000: 106).
} 
Przy czym pamiętać należy, że do własności publicznej w szerokim sensie często zalicza się także własność komunalną (municypalną), gdyż - jak zauważają badacze - „instytucjonalno-prawne formy tego typu własności w poszczególnych krajach są bardzo zróżnicowane, zależnie od takich czynników, jak np.: system podziału władzy na centralną i lokalną, tradycje demokratyczne lub ich brak czy rola samorządności lokalnej. Zróżnicowana jest też zresztą faktyczna rola własności publicznej w poszczególnych krajach” (Milewski \& Kwiatkowski 2005: 10).

Ten diachroniczny podział własności (na prywatną versus publiczną) okazuje się wysoce niewystarczający w analizach empirycznych, gdyż nie uwzględnia on kolejnej formy, która „w pewnych krajach (np. Danii) odgrywa istotną rolę” (Kozłowski 2004: 18). Chodzi o własność spółdzielczą (kooperatywną), która, choć utożsamiana z gospodarkami centralnie planowanymi, nie powinna być wyłącznie do nich zawężana, ponieważ w wysoko rozwiniętych krajach wolnorynkowych: „[...] obserwuje się utrzymywanie się specyfiki własności spółdzielczej w porównaniu z własnością państwową (np. istnienie tzw. samorządu spółdzielczego), a równocześnie burzliwy rozwój pewnych form zbiorowej własności prywatnej (zwłaszcza różnego typu spółek), przypominających pod wieloma względami spółdzielnie” (Milewski \& Kwiatkowski 2005: 10).

Dodatkowo warto zauważyć, iż własność spółdzielcza w polskich opracowaniach statystycznych ujmowana jest jako element sektora prywatnego (ibidem, przypis 3.), lecz historycznie bywała utożsamiana z własnością publiczną (państwową).

Własność publiczna Własność spółdzielcza Własność prywatna

Tego rodzaju praktykę można starać się wytłumaczyć odwołaniem do ogólnego podziału własności na prywatną i społeczną. Pierwsza w tym partykularnym ujęciu przysługiwałaby danemu podmiotowi, zaś druga wiązałaby się z podmiotem zbiorowym. Idąc tym tropem, w literaturze przedmiotu odnajdujemy zbliżony podział własności na indywidualną i grupową, a kryterium wyróżnienia tych dwóch odmian własności oparte jest na wyodrębnieniu liczby podmiotów partycypujących w danej własności.

Własność indywidualna Własność zbiorowa

Jednakże w tej klasyfikacji, odmiennie niż w powyższej, badacze wyodrębniają w obrębie własności grupowej, tj. kolektywnej, takie formy własności, jak: państwowa, spółdzielcza i komunalna.

Do tej palety form własności dodamy jeszcze jedną, określaną jako własność osobista, czyli „te dobra konsumpcyjne, które służą wyłącznie potrzebom danej jednostki i nie mogą stać się w danych stosunkach gospodarczych i społecznych przedmiotem wymiany towarowo-pieniężnej. Te same dobra konsumpcyjne przekształcają się natomiast w obiekty własności prywatnej, gdy mogą w każdej chwili być sprzedane” (Kozyr-Kowalski 2000: 124). Wynika z powyższego, iż w świetle analizy ekonomiczno-socjologicznej istnieje różnica między własnością osobistą a prywatną, które na poziomie 
potocznego dyskursu ujmowane są synonimicznie.

\section{RODZAJE PRZEDSIĘBIORSTW ZE WZGLĘDU NA TYP WŁASNOŚCI}

Charakterystyka własności ma także olbrzymi wpływ na strukturę firmy oraz mechanizmy kontrolne związane z jej zarządzaniem. Jak zauważył Stanisław Sudoł, „własność przedsiębiorstwa decyduje o tym, kto jest kapitałodawcą dla niego, kto ma w związku z tym prawo do korzyści z jego prowadzenia (udział w zysku i w przyroście wartości firmy) oraz kto ponosi ryzyko finansowe. Własność daje również prawo do decyzji dotyczących przedsiębiorstwa, tzn. do zarządzania nim” (Sudoł 2002: 111).

Okazuje się, że struktura własności przedsiębiorstwa determinuje socjologiczne i ekonomiczne aspekty jego funkcjonowania. W związku z tym, w oparciu o kryterium własności, można wyróżnić (ibidem: 112):

- przedsiębiorstwa państwowe,

- przedsiębiorstwa samorządu terytorialnego,

- przedsiębiorstwa spółdzielcze,

- przedsiębiorstwa prywatne,

- przedsiębiorstwa mieszane.

Pogłębione informacje na temat powyższych form własnościowych przedsiębiorstw, a także bardziej istotnych z punktu widzenia empirycznych badań, znaleźć można w innych opracowaniach (Baranowski 2010, 2011a, 2011b; Sudoł 2002; Williamson 1998). Jednak warto zasygnalizować inny podział, dotyczący wyłącznie spółek akcyjnych będących w publicznym obrocie. Mam na myśli takie kryterium podziału, które łączy się bezpośrednio z szeroko dyskutowaną tematyką nadzoru korporacyjnego.

\section{CORPORATE GOVERNANCE}

Termin ten w języku polskim tłumaczony jest jako nadzór właścicielski, nadzór korporacyjny, nadzór nad działalnością spółek, kontrola nad spółką, kontrola nad zarządzaniem (Działo 2001: 5). Jest on tak powszechnie używany, że wielu badaczy posługuje się jego oryginalną anglojęzyczną wersją. Jeśli chodzi o jego znaczenie, to „w wąskim sensie, corporate governance jest po prostu nadzorem nad partykularną formą organizacyjną - korporacją" (Boceau \& Barbu 2007: 125). Według Jacka Tittenbruna chodzi o „sferę relacji między kluczowymi wymiarami funkcjonowania nowoczesnej korporacji (spółki akcyjnej): zarządzaniem, kontrolą i własnością” (Tittenbrun 2005: 47).

W kontekście ostatniego sformułowania roli mechanizmów corporate governance, staje się oczywiste, iż ów nadzór właścicielski w rzeczywistości dotyczy takich komponentów analitycznych, jak: własność, kontrola i efektywność. Problem natury teoretycznej może dotyczyć bardziej szczegółowych dystynkcji, ponieważ: „W analizie corporate governance podkreśla się różnicę między badaniem nadzoru właścicielskiego a badaniem corporate governance, zwracając uwagę, że o ile nadzór właścicielski dotyczy 
głównie sposobu egzekwowania wiązki praw własnościowych (zwłaszcza relacji między akcjonariuszami i ich formalnymi przedstawicielami a zarządem), o tyle corporate governance stawia szersze pytania o formalną i częściowo także nieformalną strukturę oddziaływania na najważniejsze decyzje podejmowane przez management, nadając im wyraziste tło systemowe” (Lis \& Sterniczuk 2005: 30).

Przyjmując w badaniach perspektywę ekonomii praw własności, właściwie ograniczamy zakres eksploracji tytułowego zagadnienia do obszaru nadzoru właścicielskiego. Nie jest to rzadkość w przypadku badań polskich, gdyż „termin »nadzór właścicielski« we właściwy sposób odzwierciedla istniejącą sytuację w Polsce, gdzie zdecydowanie dominują formy tzw. nadzoru wewnętrznego. Ten rodzaj nadzoru jest zwykle kojarzony z działalnością poszczególnych organów nadzoru właścicielskiego, które są wybierane w całości bądź w przeważającej części przez właścicieli (akcjonariuszy, udziałowców). Nadzór właścicielski nie obejmuje co prawda tego, co nazywamy nadzorem zewnętrznym, ale ten ostatni nie odgrywa jak dotychczas w warunkach polskich poważniejszej roli” (Rudolf, Janusz, Stos, \& Urbanek 2002: 19-20).

Lapidarny przegląd problemów zagadnienia corporate governance, a zatem nadzoru korporacyjnego w szerokim sensie, pokazuje, iż tematyka związana z własnością i kontrolą jest tu najważniejsza. Oto konkretny wybór szczegółowych problemów nadzoru nad korporacją:

- prawa akcjonariuszy,

- zapewnienie równego traktowania akcjonariuszy,

- rola właścicieli w nadzorze korporacyjnym,

- problemy związane z publikowaniem informacji oraz ich przejrzystością i rzetelnością,

- struktura i odpowiedzialność zarządu i rad,

- kształtowanie wynagrodzeń kadry kierowniczej (Jerzemowska 2002: 8).

Spektrum zagadnień poruszanych w ramach tego specyficznego nadzoru jest więc bogate, ale jego sedno dotyczy społecznego mechanizmu kontroli nad przedsiębiorstwem, a właściwie nad każdym jego istotnym elementem. Bardzo trafną jego charakterystykę przedstawili autorzy pracy poświęconej aspektom społeczno-ekonomicznym i prawniczym omawianej tu formy kontroli. Zauważyli oni, że: „[...] nadzór korporacyjny jest pewnego rodzaju technologią kontroli społecznej nad spółkami i kadrą kierowniczą - agentami, którzy operują cudzym kapitałem. Skuteczność tej technologii pośredniej kontroli, zastępującej bezpośredni udział właścicieli w rozporządzaniu swoim kapitałem, ma szczególne znaczenie w sytuacji poważnego rozproszenia akcji właścicielskich, gdy samodzielnie żaden z akcjonariuszy nie jest w stanie w poprawny sposób kształtować sytuacji w zarządzaniu, z kolei wszyscy są zmuszeni do akceptacji roli kadry zarządzającej spółką w rozporządzaniu ich inwestycjami” (Lis \& Sterniczuk 2005: 53). 
Mając na uwadze powyższą konstatację, warto pamiętać o tym, że zestawiając np. firmy kontrolowane przez właścicieli ze spółkami menedżerskimi w aspekcie efektywności, tak naprawdę porównujemy „klasyczny” typ przedsiębiorstwa z relatywnie nową odmianą spółki (opartą na mechanizmach nadzoru korporacyjnego). Wynik tej konfrontacji w sposób pośredni, gdyż zazwyczaj ograniczony do niereprezentatywnej grupy spółek notowanych na giełdzie, winien dać odpowiedź, czy współczesne rozwiązania mechanizmu corporate governance sprawdzają się w praktyce życia społeczno-gospodarczego (por. Baranowski 2011a; Baranowski \& Pluciński 2018; Husson 2019; Toporowski 2019).

\section{PODSUMOWANIE}

Artykuł ten miał za zadanie w sposób bardzo ogólny zaprezentować skomplikowaną materię dotyczącą zagadnienia własności. Zagadnienia niezwykle wewnętrznie zróżnicowanego, które dodatkowo jest eksplorowane przez wiele dyscyplin, a historia jego „krystalizacji” wiąże się zarówno z systemami religijnymi, jak i świeckim prawem rzymskim. Jedną z konsekwencji tak szerokiego zakresu omawianego zagadnienia jest fakt, iż „znaczenie własności w sferze stosunków społecznych nie wyczerpuje się na jej roli jako kategorii prawnej i ekonomicznej, własność bowiem jest - jeżeli można użyć takiego określenia - zjawiskiem wszechstronnym, dającym o sobie znać we wszystkich dziedzinach życia każdej zbiorowości. Występuje w polityce, bo panujący w danym kraju typ własności charakteryzuje jego ustrój społeczno-gospodarczy; własność prywatna jest warunkiem sine qua non ustroju demokratycznego, a dominacja własności państwowej jest charakterystyczna dla niektórych totalitaryzmów. Znajdujemy ją również w socjologii i psychologii, bo powszechny dostęp do własności jest gwarancją wolności jednostki, a własność, jako jedno z podstawowych praw człowieka, zapewnia mu poczucie bezpieczeństwa w grupie społecznej, w której rozwija on swą działalność” (Ignatowicz 2000:42).

Ten interdyscyplinarny walor własności, a właściwie świadomość jego istnienia, jest bardzo ważnym elementem socjologii ekonomicznej, gdyż stanowi on podstawę rozumienia współczesnych stosunków socjoekonomicznych i politycznych (por. Baranowski 2019). Perspektywa ta dotyczy jednego z aspektów własności (własność spółek giełdowych w powiązaniu z mechanizmami kontroli), badanego za pomocą socjologii ekonomicznej. A zatem z natury „wszechstronny” problem może rozstrzygnięty zostać za pomocą interdyscyplinarnego podejścia (socjologiczno-ekonomicznego), wspartego teorią praw własnościowych jako podłoża teoretycznego (Baranowski 2011b, 2021).

\section{BIBLIOGRAFIA}

Arystoteles. 1964. Polityka. Tłum. L. Piotrowicz. Warszawa: Państwowe Wydawnictwo Naukowe.

Baranowski, Mariusz. 2010. “Trust in Comparative Perspective. An Economic Sociolo- 
gy Approach to the Issue of Corporate Governance.” Człowiek i Społeczeństwo 31: 65-74.

Baranowski, Mariusz. 2011a. Efektywność corporate governance w Polsce. Socjologiczno-ekonomiczna analiza spółek giełdowych. Poznań: Wydawnictwo Naukowe WSNHiD.

Baranowski, Mariusz. 2011b. „The Property Rights Theory Approach from a Socio-Economic Viewpoint.” Studia Historiae Oeconomicae 29: 3-16.

Baranowski, Mariusz. 2019. “Cywilizacja nierówności: Teoretyczne i praktyczne granice rozwoju społeczeństwa.” Athenaeum 62(2): 45-64. DOI: 10.15804/athena.2019.62.03

Baranowski, Mariusz. 2021. „The Sharing Economy: Social Welfare in a Technologically Networked Economy." Bulletin of Science, technology \& Society 1-11. https://doi.org/10.1177/02704676211010723

Baranowski, Mariusz \& Przemysław Pluciński. 2018. „Własność i społeczeństwo: wybrane aspekty socjologii Jacka Tittenbruna.” Nowa Krytyka 40: 19-38. DOI: $10.18276 /$ nk.2018.40-01

Boceau, Claudiu G. \& Cătălin M. Barbu. 2007. “Corporate Governance and Firm Performance.” Management\&Marketing-Craiova 1: 125-131.

Chmara, Michał. 1992. "Some Social Classes Are More So. Remarks on the Contribution of Latin American Sociology.” W: S. Kozyr-Kowalski, M. Chmara, \& J. Heymann (red.). On Social Differentiation. A Contribution to the Critique of Marxist Ideology. Poznań: Adam Mickiewicz Univeristy Press.

Dębiński, Antoni. 2007. Rzymskie prawo prywatne. Kompendium. Warszawa: Wydawnictwo Prawnicze LexisNexis.

Działo, Joanna. 2001. Nadzór właścicielski a efektywność działania spółek. Łódź: Katedra Ekonomii Uniwersytetu Łódzkiego.

Filipowicz, Andrzej. 1999. Prawo dla ekonomistów. Warszawa: Oficyna Prawnicza MUZA S.A.

Ford, Laura R. 2010. "Max Weber on Property: An Effort in Interpretive Understanding.” Socio-Legal Review 6: 24-100. https://papers.ssrn.com/sol3/papers.cfm?abstract $\underline{\mathrm{id}=1560042}$

Hamilton, Malcolm \& Maria Hirszowicz. 1995. Klasy i nierówności społeczne w perspektywie porównawczej Tłum. J. Kolbowski. Warszawa: Instytut Studiów Politycznych PAN.

Hobbes, Tomasz. 1954. Lewiatan czyli materia, forma i władza państwa kościelnego $i$ świeckiego. Tłum. C. Znamierowski. Warszawa: Państwowe Wydawnictwo Naukowe.

Husson, Michel. 2019. "How Mainstream Economists Explain (or not) Unemployment?" Society Register 3(2): 21-37. https://doi.org/10.14746/sr.2019.3.2.02

Ignatowicz, Jerzy. 2000. Prawo rzeczowe, wydanie IX. Warszawa: Wydawnictwa Prawnicze PWN.

Jaruzelska, Izabela. 1992. Własność w prawie biblijnym. Warszawa: Wydawnictwo Naukowe PWN.

Jerzemowska, Magdalena. 2002. Nadzór korporacyjny. Warszawa: Polskie Wydawnic- 
two Ekonomiczne.

Kodeks Hammurabiego. 1996. Tłum. M. Stępień. Warszawa: Wydawnictwo ALFA.

Kolańczyk, Kazimierz. 2001. Prawo rzymskie, wydanie V zmienione. Warszawa: Wydawnictwo Prawnicze LexisNexis.

Kozłowski, Sławomir G. 2004. Systemy ekonomiczne. Lublin: Wydawnictwo Uniwersytetu Marii Curie-Skłodowskiej.

Kozyr-Kowalski, Stanisław. 1977. „Własność jako zjawisko ekonomiczno-społeczne w świetle badań Karola Marksa i Maxa Webera.” W: tenże (red.). Własność: gospodarka a prawo. Studia o marksistowskiej teorii własności. Warszawa: Państwowe Wydawnictwo Naukowe.

Kozyr-Kowalski, Stanisław. 2000. Socjologia, społeczeństwo obywatelskie i państwo. Poznań: Wydawnictwo Naukowe UAM.

Kunderewicz, Cezary. 1995. Rzymskie prawo prywatne, wydanie II. Łódź: Wydawnictwo Uniwersytetu Łódzkiego.

Landreth, Harry \& David C. Colander. 1998. Historia myśli ekonomicznej. Tłum. A. Szeworski. Warszawa: Wydawnictwo Naukowe PWN.

Lis, Krzysztof A. \& Henryk Sterniczuk. 2005. Nadzór korporacyjny. Kraków: Oficyna Ekonomiczna.

Litewski, Wiesław. 2003. Rzymskie prawo prywatne, wydanie V poprawione. Warszawa: Wydawnictwo Prawnicze LexisNexis.

Locke, John. 1992. Dwa traktaty o rządzie. Tłum. Z. Rau. Warszawa: Wydawnictwo Naukowe PWN.

Marks, Karol. 1986. Zarys krytyki ekonomii politycznej. Tłum. Z. J. Wyrozembski. Warszawa: Wydawnictwo „Książka i Wiedza”.

Marks, Karol \& Fryderyk Engels. 1979. Manifest partii komunistycznej. Zasady komunizmu. Warszawa: Książka i Wiedza.

Milewski, Roman \& Eugeniusz Kwiatkowski. 2005. Podstawy ekonomii. Wydanie III, zmienione. Warszawa: Wydawnictwo Naukowe PWN.

Morawski, Witold. 2001. Socjologia ekonomiczna. Problemy. Teoria. Empiria. Warszawa: Wydawnictwo Naukowe PWN.

Morus, Thomas. 1993. Utopia. Tłum. K. Abgarowicz. Lublin: Instytut Wydawniczy „Daimonion".

Nowak, Leszek. 1991. U podstaw teorii socjalizmu. Tom I. Własność i władza. O konieczności socjalizmu. Poznań: Wydawnictwo Nakom.

Osuchowski, Wacław. 1986. Rzymskie prawo prywatne. Zarys wykładu. Warszawa: Państwowe Wydawnictwo Naukowe.

Pels, Dick. 1998. Property and Power in Social Theory. A Study in Intellectual Rivalry. London: Routledge.

Pipes, Richard. 2000. Własność a wolność. Tłum. L. Niedzielski. Warszawa: Warszawskie Wydawnictwo Literackie MUZA S.A.

Piwowarun, Tomasz. 1977. „Teoretyczne problemy własności jako zjawiska ekonomiczno-społecznego.” W: S. Kozyr-Kowalski (red.). Własność: gospodarka a prawo. Studia o marksistowskiej teorii własności. Warszawa: Państwowe Wydawnictwo Naukowe. 
Platon. 1994. Państwo. Tom I. Tłum. W. Witwicki. Warszawa: Wydawnictwo ALFA.

Popper, Karl R. 1999. Nędza historycyzmu. Tłum. S. Amsterdamski. Warszawa: Wydawnictwo Naukowe PWN.

Popper, Karl R. 1993a. Społeczeństwo otwarte i jego wrogowie. Tom1. Urok Platona. Tłum. H. Krahelska. Warszawa: Wydawnictwo Naukowe PWN.

Popper, Karl R. 1993b. Społeczeństwo otwarte i jego wrogowie. Tom 2. Wysoka fala proroctw: Hegel, Marks i następstwa. Tłum. H. Krahelska. Warszawa: Wydawnictwo Naukowe PWN.

Reale, Giovanni. 1997. Historia filozofii starożytnej, II: Platon i Arystoteles. Tłum. E. I. Zieliński. Lublin: Redakcja Wydawnictw Katolickiego Uniwersytetu Lubelskiego.

Rousseau, Jean J. 1956. „Rozprawa o pochodzeniu i podstawach nierówności między ludźmi.” W: tenże. Trzy rozprawy z filozofii społecznej. Tłum. H. Elzenberg. Warszawa: PWN.

Rozwadowski, Władysław. 1994. Prawo rzymskie. Zarys wykładu wraz z wyborem źródeł. Wydanie II. Poznań: Ars Boni et aequi.

Rudolf, Stanisław, Tadeusz Janusz, Daniel Stos, \& Piotr Urbanek. 2002. Efektywny nadzór korporacyjny. Teoria i praktyka. Warszawa: Polskie Wydawnictwo Ekonomiczne.

Shleifer, Andrei. 1998. “State versus Private Ownership.” The Journal of Economic Perspectives 12(4): 133-150. DOI: 10.1257/jep.12.4.133

Smith, Adam. 2007a. Badania nad naturą i przyczynami bogactwa narodów. Tom 1. Tłum. S. Wolff, O. Einfeld, Z. Sadowski. Warszawa: Wydawnictwo Naukowe PWN.

Smith, Adam. 2007b. Badania nad naturą i przyczynami bogactwa narodów. Tom 2. Tłum. A. Prejbisz, B. Jasińska. Warszawa: Wydawnictwo Naukowe PWN.

Stępień, Marek. 1996. „Wprowadzenie.” W: Kodeks Hammurabiego. Tłum. Tenże. Warszawa: Wydawnictwo ALFA.

Strzeszewski, Czesław. 2003. Katolicka nauka społeczna. Lublin: Wydawnictwo KUL.

Sudoł, Stanisław. 2002. Przedsiębiorstwo. Podstawy nauki o przedsiębiorstwie. Teorie $i$ praktyka zarządzania. Wydanie II rozszerzone. Toruń: Wydawnictwo „Dom Organizatora”.

Szacki, Jerzy. 2004. Historia myśli socjologicznej. Wydanie nowe. Warszawa: Wydawnictwo Naukowe PWN.

The New Encyclopædia Britannica. 1991. 15 th Edition, Vol. 26. Chicago: MACROPÆDIA. Tittenbrun, Jacek. 1995. Ekonomiczny sens prywatyzacji. Spór o wyższość własności prywatnej nad publiczną. Poznań: Wydawnictwo Fundacji Humaniora.

Tittenbrun, Jacek. 1996. Private versus Public Enterprise. In Search of the Economic Rationale for Privatisation. London: Janus Publishing Company.

Tittenbrun, Jacek. 2005. „Opowieści o dwóch kapitalizmach: kapitalizm akcjonariuszy vs. kapitalizm interesariuszy.” W: A. Sakson (red.) Porządek społeczny a wyzwania współczesności. Poznań: Wydawnictwo Naukowe.

Tittenbrun, Jacek. 2012. Gospodarka w społeczeństwie. Zarys socjologii gospodarki i socjologii ekonomicznej w ujęciu strukturalizmu socjoekonomicznego. Poznań: Wydawnictwo Zysk i S-ka.

Tomasz Hobbes i Lewiatan. 1954. W: T. Hobbes. Lewiatan czyli materia, forma i władza 
państwa kościelnego i świeckiego. Tłum. C. Znamierowski. Warszawa: Państwowe Wydawnictwo Naukowe.

Toporowski, Jan. 2019. “Financial Control and the Employer of Last Resort.” Society Register 3(2): 39-48. https://doi.org/10.14746/sr.2019.3.2.03

Tuck, Richard. 2001. The Rights of War and Peace. Political Thought and the International Order. From Grotius to Kant. Oxford-New York: Oxford University Press.

Tyszka, Tadeusz. 2004. Psychologia ekonomiczna. Gdańsk: Gdańskie Wydawnictwo Psychologiczne.

Weber, Max. 1985. „Obiektywność poznania w naukach społecznych.” W: E. Nowakowska-Sołtan (red.). Problemy socjologii wiedzy. Warszawa: Państwowe Wydawnictwo Naukowe.

Weber, Max. 2002. Gospodarka i społeczeństwo. Zarys socjologii rozumiejącej. Tłum. D. Lachowska. Warszawa: Wydawnictwo Naukowe PWN.

Wesołowski, Włodzimierz. 1979. „Prawa rozwoju społecznego.” W: T. M. Jaroszewski (red.). Filozofia marksistowska. Wydanie VI. Warszawa: Państwowe Wydawnictwo Naukowe.

Williamson, Oliver E. 1998. Ekonomiczne instytucje kapitalizmu. Firmy, rynki, relacje kontraktowe Tłum. J. Kropiwnicki. Warszawa: Wydawnictwo Naukowe PWN.

Zagóra-Jonszta, Urszula. 2007. „Własność w ujęciu wybranych kierunków myśli ekonomicznej.” W: B. Polaszkiewicz \& J. Boehlke (red.). Własność $i$ kontrola $w$ teorii $i$ praktyce. Część I. Torun: Wydawnictwo Uniwersytetu Mikołaja Kopernika.

Zaleski, Zbigniew. 2003. Psychologia własności i prywatności. Warszawa: Wydawnictwo Akademickie „Żak”.

Zaleśkiewicz, Tomasz. 2003. Psychologia inwestora giełdowego. Wprowadzenie do behawioralnych finansów. Gdańsk: Gdańskie Wydawnictwo Psychologiczne.

\section{Ownership in sociological terms: An overview}

ABSTRACT: The article deals with the characteristics of ownership from a sociological or, more precisely, socio-economic perspective. The article aims to highlight the difference between the legal and sociological approach to the issue of ownership, especially in the context of studying modern companies. The review of selected approaches to ownership is subordinated to articulating the complicated nature of corporate governance, the fuller understanding of which enables tracing the legal and sociological and economic fate of this specific social relationship.

KEYWORDS: ownership, possession, corporate governance, socio-economic analysis, economic sociology 